\title{
Sine qua non-sense: originality and the end of copyright
}

The sine qua non of copyright is originality. ${ }^{1}$

The English humourist, Thomas Hood, wrote in his Preface to the 1869 edition of his Whims and Oddities: 'there is, I am aware, a kind of nonsense indispensable, - or sine qua non-sense - that always comes in welcomely to relieve the serious discussions of graver authors, and I flatter myself that my performances may be of this nature'. ${ }^{2}$ It is hoped that the following is a welcome and indispensable nonsense on the current state of copyright.

This past August, New Zealand's prestigious drawing award, the Parkin Drawing Prize, was won by Poppy Lekner's work, Forward Slash. ${ }^{3}$ The work was described in the press as 'An A4 piece of paper with thousands of forward-slash characters on it from a typewriter'. ${ }^{4}$ Lekner described the piece as, 'an intimate meditation and mark making experience', ${ }^{5}$ and the head judge, Charlotte Davy, interpreted it as, 'a kind of meditation of process'. ${ }^{6}$ But, perhaps unwittingly, it also offers a mesmerizing meditation upon copyright. One law's trash may be another art's treasure.

Each year the winning piece is acquired (by default) by the prize's funder and namesake, Chris Parkin. Parkin told journalists, 'The judges are always looking for something innovative, something that's gone a bit beyond', and said that the winning piece is almost always 'something that doesn't look in any way [in] the conventional sense like a drawing'. ${ }^{7}$ As Parkin asserts, 'It's totally unpredictable ... it's a recognition that nothing in art succeeds like recognition'. ${ }^{8}$ The subject of the recognition is key.

Nevertheless, the anxiety over the definition of the work persisted. In something of a defence of this year's winner, the artist herself, Poppy Lekner, describes Forward

1. Feist Publications, Inc. v Rural Telephone Service Co., 499 U.S. 340 (1991), per O'Connor J, at 3.

2. T Hood, Whims and Oddities in Prose and Verse: With Eighty-Seven Original Designs (E Moxon \& Co, London 1869) xii.

3. <https://parkinprize.nz/poppy\%20lekner\%20wins\%20parkin\%20drawing\%20prize\% $202020>$.

4. A Chumko, 'A4 Piece of Paper with Typed Forward Slashes Wins $\$ 25,000$ Art Prize', Stuff, 3 August $2020<$ https://www.stuff.co.nz/entertainment/arts/122291792/a4-piece-ofpaper-with-typed-forward-slashes-wins-25000-art-prize>. The work can be viewed on the artist's Instagram page, @ poppylekner <https://www.instagram.com/p/CDdtuz5Mba-/? utm_source=ig_embed\&utm_campaign=loading\&hl=en $>$.

5. M Nightingale, 'Forward Slash Artwork: Claims Poppy Lekner's Winning Piece "Not Original", New Zealand Herald, 10 August $2020<$ https://www.nzherald.co.nz/nz/news/article. cfm?c_id=1\&objectid=12355322>.

6. 'Drawing Featuring Typed Forward Slashes Wins Art Competition', Sky News, 4 August $2020<\mathrm{https}$ ://news.sky.com/story/new-zealand-drawing-featuring-typed-forward-slashes-winsart-competition-12041955>.

7. Chumko (n 4).

8. Ibid. 
Slash as questioning 'what is or isn't considered a drawing' ${ }^{\text {'9 }}$ and as offering 'a different way to look at what drawing can be'. ${ }^{10}$ A bit beyond, if you will. And almost inevitably, as a result of going 'a bit beyond', the name of the competition itself has faced the same questions and criticism. Past controversies have led to calls to rename it the Parkin Art Prize and the events of this year's competition have added to these. One fellow competitor, Alan MacDonald, suggested a name change to 'The Emperor's New Clothes Design Award' (also apparently rejected!) and described Lekner's piece as both unoriginal and not a drawing: 'Apart from the piece not being original, twice over, it is also not a drawing, anymore [than] that pile of carpet that won previously. ${ }^{11} \mathrm{He}$ went further to state, 'The message from the artists is simple: either change the name of the competition to Parkin Art Award or employ only drawing experts, not conceptual artist academics, as judges. This nonsense of 'questioning' what drawing is, is pure emperor's new clothes territory.' 12 Nevertheless, to date, these calls have continued to be resisted. Parkin himself explains, 'If asked to define drawing, I would be interested to know what their definition was. We've chosen not to wrap rules around it.' 13

The audacity of attempts at defining, indeed framing, contemporary art has been challenged repeatedly by artists and theorists alike. In the hugely influential essay, 'Sculpture in the Expanded Field', art critic and historian, Rosalind Krauss, describes an expanded field of sculpture, beyond its premodern monumentalism, thus encountering 'rather surprising things [that] have come to be called sculpture'.${ }^{14}$ Krauss contends that 'sculpture is no longer the privileged middle term between two things that it isn't. Sculpture is rather only one term on the periphery of a field in which there are other, differently structured possibilities. ${ }^{15}$ Krauss suggests the same expansion in painting (and arguably, by implication, also in drawing) 'that would probably turn on the opposition uniqueness/reproducibility', ${ }^{16}$ an opposition that underpins notions of originality. If only the jurists had read Krauss before the infamous Stormtrooper helmet decision in Lucasfilm v Ainsworth ${ }^{17}$ - Rosalind Krauss is indeed the Cofemel $^{18}$ court's precursor.

Long before Levola ${ }^{19}$ and Cofemel, Krauss was rejecting the modernist categorical imperative, as it were, for art: 'practice is not defined in relation to a given medium sculpture - but rather in relation to the logical operations on a set of cultural terms,

9. Ibid.

10. Poppy Lekner quoted in 'Drawing Featuring Typed Forward Slashes Wins Art Competition', Sky News, 4 August 2020, <https://news.sky.com/story/new-zealand-drawingfeaturing-typed-forward-slashes-wins-art-competition-12041955>.

11. Alan MacDonald quoted in Nightingale (n 5). The 'pile of carpet' to which MacDonald is referring is the 2017 winner, Kirsty Lillico's work, State Block. See further, 'Parking Drawing Prize Worth $\$ 20,000$ Awarded to a Pile of Carpet', Stuff, 1 August $2017<$ https://www.stuff.co. nz/entertainment/arts/95334929/parkin-drawing-prize-worth-20000-awarded-to-a-pile-of-carpet>.

12. Alan MacDonald quoted in Nightingale (n 5).

13. Nightingale (n 5).

14. RE Krauss, 'Sculpture in the Expanded Field', in The Originality of the Avant-Garde and Other Modernist Myths (The MIT Press, Cambridge 1979/[1986]) 277-90, 277. First published, RE Krauss, 'Sculpture in the Expanded Field' (1979) 8 October 30-44.

15. Krauss (1979/[1986]) (n 14) 284.

16. Ibid 289.

17. [2011] UKSC 39.

18. C-683/17 Cofemel, EU:C:2019:721.

19. C-310/17 Levola Hengelo, EU:C:2018:899. 
for which any medium - photography, books, lines on walls, mirrors, or sculpture itself might be used'. ${ }^{20}$ Just as Krauss argued for modern and contemporary art, Levola and Cofemel have similarly confirmed an 'expanded field' of the copyright work. These decisions thus move copyright away from the convention in some jurisdictions, including the UK, of a closed list of works, ${ }^{21}$ thus leading to an expanded field of copyright in which anything that is original to the author is capable of being a work. Whether it be a sculpture, a drawing, or a sweatshirt, ${ }^{22}$ as long as it is original subject matter of the author's own intellectual creation then it is capable of being a work. Expression may be temporary as long as it is identifiable with precision and certainty. ${ }^{23}$ In other words, copyright knows art when it sees it.

Surveying that expanded field therefore rests on a persistent landmark - originality. In this way, recent judgments of the Court of Justice affirm copyright's reliance on the 'vanguardist discourse' of modernism; that is, 'the theme of originality'. ${ }^{24}$ And in that, the brand of the author is complicit. As Krauss explains: 'The self as origin is the way an absolute distinction can be made between a present experience de novo and a traditionladen past. The claims of the avant-garde are precisely these claims to originality., 25 A work is thus a work precisely because of the value of originality. In Levola, the two limbs of the test have a startling (and oft-criticized) circularity: 'the subject matter concerned must be original in the sense that it is the author's own intellectual creation' 26 and 'only something which is the expression of the author's own intellectual creation may be classified as a "work". ${ }^{27}$ The test appears at first to be frustratingly tautological; but the aporesis of these paragraphs gives both a functional and a revealing 'infinity', as it were, to the jurisprudence of originality. Copyright imitates art. Originality equals originality. It is both the beginning and the end of the work.

To return, as it were, to Krauss's interrogation of the opposition between uniqueness and reproducibility, the question of the copy is one of the 'original' questions of art. What happens when originality is repeated? The history of the art world's turbulent relationship with prints is fascinating not only with respect to the economics of copyright, but also, and more tellingly, for the frustration of the purview of originality. And, of course, the mischief with consumer products in the art of the readymade, at once both everything and nothing original, is a fascinating disruption for copyright discourse. How might we trust the expression of Duchamp's Fountain, when the only thing of which we can be certain is the persistence of the idea. All the known examples of Fountain on display around the world are 'copies'. And yet, they are all 'original'. The fundamental condition of originality is the copy: 'if the very notion of the avantgarde can be seen as a function of the discourse of originality, the actual practice of

\section{Krauss (1979/[1986]) (n 14) 288.}

21. C-310/17 Levola Hengelo, EU:C:2018:899, para 39: 'Under Article 2(1) of the Berne Convention, literary and artistic works include every production in the literary, scientific and artistic domain, whatever the mode or form of its expression may be'.

22. C-683/17 Cofemel, EU:C:2019:721, para 48.

23. C-310/17 Levola Hengelo, EU:C:2018:899, para 40: 'Accordingly, for there to be a "work" as referred to in Directive 2001/29, the subject matter protected by copyright must be expressed in a manner which makes it identifiable with sufficient precision and objectivity, even though that expression is not necessarily in permanent form'.

24. RE Krauss, 'The Originality of the Avant-Garde' in The Originality of the Avant-Garde and Other Modernist Myths (The MIT Press, Cambridge 1981/[1986]), 151-70, 157.

25. Ibid 157.

26. C-310/17 Levola Hengelo, EU:C:2018:899, para 36.

27. Ibid para 37. 
vanguard art tends to reveal that "originality" is a working assumption that itself emerges from a ground of repetition and recurrence'. ${ }^{28}$

Once again, the episode in New Zealand provokes some answers. Thus, to address this question it is useful to revert to type, so to speak. The subsequent controversy attending Lekner's work overwhelmed the question of what is a drawing, obscuring it with the question of what is or is not originality. Within days, claims of plagiarism were made and the work's originality was questioned in relation to an earlier similar work from US artist, Joel Swanson, also entitled Forward Slash ${ }^{29}$ The alleged plagiarism was raised apparently by several people ${ }^{30}$ although in crafting the drama of a modern authorship rivalry, most articles attribute the claim to Alan MacDonald. ${ }^{31}$ Swanson responded to the controversy: "While I have no reason to believe that the similar work in question was created intentionally or maliciously, this situation highlights how important it is for artists and institutions to vet their work and ideas. 32 Further, Lekner's and Swanson's pieces are themselves both similar to Dattilograme Typewriter Poem, a 1964 piece by Maurizio Nannucci. ${ }^{33}$ This earlier significant work was also raised in responses to the announcement of the controversial winner: 'The judges should have been aware of this artist as he is the leading artist of this movement called concrete poetry.' 34

Of course, typewriter art and concrete poetry go back even further than Nannucci's work. ${ }^{35}$ However, even in acknowledging this tradition, the distraction here is the characterization of the work through the tool. The use of a typewriter is not in and of itself the original element, the subject of originality. What, then, is original about Forward Slash and Forward Slash? If not the tool, if not the object, then what is original about this series of marks? The comments of the competition's head judge usher in what at first might seem a curious, or even irrelevant, reference to context. In the midst of this plagiarism controversy, Charlotte Davy stated, 'We are confident that there has been no plagiarism with the prize-winning work - in our view the similarities are coincidental and the artists are each working in a different context with differing concerns. ${ }^{36}$ What might it mean to consider an artist working in a different context? What might it mean to introduce the space of 'performance' beyond the emphasis on the artefact of the idea? ${ }^{37}$ Is such 'performance' in art a work, or is it protected only by

\section{Krauss (n 24) 157-8.}

29. Swanson's Forward Slash may be viewed here <https://octopus.mcadenver.org/art/joelswanson/forward-slash>. Swanson's work may also be viewed via his Instagram page, @joel.swanson including a photographic image of the forward slash work with the typewriter, posted with the title, 'I $\bullet$ Repetition' <https://www.instagram.com/p/BstgjtQH8o7/?utm_source=ig_embed>. 30. J Bailey, 'Plagiarism vs. Independent Creation', Plagiarism Today, 6 August 2020 $<$ https://www.plagiarismtoday.com/2020/08/06/plagiarism-vs-independent-creation/>.

31. Nightingale (n 5).

32. Ibid.

33. The work may be viewed in C Dunne, 'Looking Back on 100 Years of Typewriter Art', 12 October $2015<$ https://hyperallergic.com/242249/looking-back-on-100-years-of-typewriter-art/>. 34. M Tso, 'Parkin Drawing Prize Winner Denies Accusation of Plagiarism', Stuff, 6 August 2020 $<$ https://www.stuff.co.nz/national/300076143/parkin-drawing-prize-winner-denies-accusation-ofplagiarism>.

35. Dunne (n 33).

36. Nightingale (n 5).

37. There is of course the separate regime of performers' rights, not to be confused with this idea of performance in art. Notably, performers' rights have no requirement of originality, they arise in relation to a fixed performance. The regime of performers' rights raises important 
scandal, only by brand? It may or may not be plagiarism. It may or may not be independent creation. But is it original?

From Marcel Duchamp to Elaine Sturtevant, from Sherrie Levine and Walker Evans, to Sherrie Levine and Michael Mandiberg, to Richard Prince and Instagram, modern art's self-conscious relationship with originality and repetition is at the same time an almost whimsical disregarding regard for the provenance suggested by a layer of copyright. Sherrie Levine re-photographed the famous early Depression-era photography of Walker Evans and recast these in the work, After Walker Evans. ${ }^{38}$ Subsequently, Michael Mandiberg scanned the photographs and created two sites to archive the images. ${ }^{39}$ In this way, what is being disseminated and sustained is the process or performance, through the legacy of subsequent artists and audiences, as distinct from the artefact itself - through repetition, as it were, rather than origination. The two sites, AfterWalkerEvans.com ${ }^{40}$ and AfterSherrieLevine.com, ${ }^{41}$ communicate back and forth to each other in an aporetic self-equivalence. The photographic image becomes incomparable, not unlike the forward slash, in an infinity of the 'original' aesthetic. It is a strikingly ironic twist in the Forward Slash episode, that Parkin describes the judges as looking for 'something that's gone a bit beyond', when the view is that of the aporesis of Lekner, Swanson and Nannucci. Originality, as it were, is disproved by the artefacts of innovation and affirmed by the audience.

The originality of this 'performance' is arguably a central concern for another socalled 'Pictures' artist, Richard Prince, whose notorious re-presentation of Instagram images is regularly bumping up against copyright. In some senses, the controversy following Prince is part of the originality of the art, not as object, but to return to an earlier point, as performance. To some extent, this space of performance is 'expressed' and recognized through the brand of the artist (and the associated scandal). ${ }^{42}$ However, Lisa Phillips, the influential director of New York's New Museum of Contemporary Art, makes a more interesting claim. In response to the Prince disputes, she has stated that, 'An image need not be altered to be transformed into a new work of art.'43 Richard Prince's work may be original, but is it copyright?

Again, to return to type, is Forward Slash even eligible for copyright protection? The legacy of precursors aside, a further preoccupation highlighted by this episode

questions for originality, copyright and the treatment of performers, outside the scope of the present discussion, although I consider originality and performance elsewhere (J Gibson, Wanted, More than Human Intellectual Property: Animal Authors and Human Machines (Routledge, London forthcoming)).

38. <https://www.metmuseum.org/art/collection/search/267214>.

39. <https://afterwalkerevans.com and https://aftersherrielevine.com>.

40. <https://afterwalkerevans.com>.

41. <https://aftersherrielevine.com>.

42. Amy Whitaker, Assistant Professor of Visual Arts Administration, NYU, describes an admiration for 'the imaginativeness required to wrest [transformative] meaning from five words and one emoji', but nevertheless, without mentioning the work of the audience, she maintains that this 'rests solely' on the 'brand of the artist'. This perspective explicitly refers to a kind of labour model of artistic value, with the accompanying implication of a quantitative assessment of originality. See further, L Gilbert, 'Richard Prince Defends Reuse of Others' Photographs', The Art Newspaper, 10 October 2018 <https://www.theartnewspaper.com/news/ richard-prince-defends-re-use-of-others-photographs $>$.

43. Quoted in Gilbert, ibid. 
is the relationship between the 'labour' of the artist and the 'value' of the work. Notably, the location for this story is New Zealand, where the author's own time, skill, labour and judgment remain relevant. ${ }^{44}$ However, in the US and EU, the fundamental test is originality, and labour and skill are no longer relevant considerations. But while copyright law might pretend at dismantling the criterion of labour, is labour nevertheless persistent in the interpretation of a 'de minimis quantum of creativity' ${ }^{45}$ or 'author's own intellectual creation'? ${ }^{46}$ Are the claims to originality by copyright jurisprudence somewhat disingenuous? Are we seducing ourselves with a concept that is both sublime and ridiculous? In the application of these tests for 'originality', arguably a concern with the work's 'worth' remains. Lekner infamously raised the heckles of fellow competitors when she said she decided to enter the competition the day before and completed the work the night before the closing date, ${ }^{47}$ provoking a discussion of the artistic labour and months of preparation described by other competitors who detailed the sometimes hundreds of hours in producing a work. ${ }^{48}$ The reactions reinforced the way in which prizes and competitions operate as part of the industry and social infrastructure endorsing the authorship narrative and the public construction of and consensus on value. Responding to the Parkin controversy, one artist, Natalie Britten, describes this kind of process of recognition and the relationship to work: 'I work on my artwork tirelessly, so being accepted is recognition of all the hard work I put into this piece. The last few months before the deadline were particularly full on.' 49

This Enlightenment narrative of authorship is part of the cultural, social and professional context for the relationship between art and copyright, but is there an impact on jurisprudence? Is there an unstated requirement for a de minimis labour in originality ? $^{50}$ Whether originality is described as personality, creativity, or the author's own intellectual creation, authorship - and the effort perceived as going with that - is the gatekeeper. How else might copyright protect a narrative of 'innovation' in the arts, if not through an originality which continues to be premised upon an artifice of difference and labour, however it might be re-presented as creativity? Only in this way is there 'progress' in

44. University of Waikato v Benchmarking Services (2004) 8 NZELC 101, 561.

45. Feist Publications, Inc. v Rural Telephone Service Co., 499 U.S. 340 (1991), per O'Connor J, at 9.

46. C-5/08 Infopaq International, EU:C:2009:465.

47. 'Drawing Featuring Typed Forward Slashes Wins Art Competition', Sky News, 4 August $2020<$ https://news.sky.com/story/new-zealand-drawing-featuring-typed-forward-slashes-winsart-competition-12041955>.

48. M Nightingale, 'Artists Reveal Work Put into Parkin Drawing Prize Pieces Amid Controversy', 12 August $2020<$ https://www.nzherald.co.nz/nz/news/article.cfm?c_id=1\& objectid $=12355642>$.

49. Quoted in Nightingale, ibid.

50. A recent second request to register with the US Copyright Office several artworks comprising fingerprints scanned and altered into various geometric shapes was denied, the Board finding 'that the Works do not contain the requisite authorship necessary to sustain claims to copyright'. By implication in the reasoning that follows, authorship is a kind of 'sufficient creativity' that can be decipherable through elements which together will meet the minimum requirement of creativity. This is a curiously quantitative analysis for a criterion that is presented as departing from effort or labour. See further the Decision of United States Copyright Office Review Board, 7 August 2020. 
the arts. And as Kurt Vonnegut cautions, 'You can't fight progress. The best you can do is ignore it, until it finally takes your livelihood and self-respect away. ${ }^{, 51}$

In any event, it does not make a difference to art, so to speak. Originality in copyright is sine qua non-sense. And if you can't be original, be different.

Johanna Gibson

September 2020

51. K Vonnegut, Bagombo Snuff Box: Uncollected Short Fiction (G.P. Putnam's Sons, New York 1999) 8. 